\title{
Understanding how to increase hydroponic attractiveness: Economic and ecological benefit
}

\author{
Tengku Ezni Balqiah ${ }^{1 *}$, Andreas Pardyanto $^{2}$, Rifelly Dewi Astuti ${ }^{1}$, Syahrial Mukhtar ${ }^{3}$ \\ ${ }^{1}$ Faculty Economics and Business, Universitas Indonesia, Depok, 16424, Indonesia. \\ ${ }^{2}$ Doctoral Program in Management, Universitas Indonesia, Depok, 16424, Indonesia. \\ ${ }^{3}$ Faculty Economics and Business, Universitas Indonesia, Jakarta, 10430, Indonesia
}

\begin{abstract}
As one of the sustainable food, hydroponic vegetables begin to attract consumer attention. Previous studies focus on how to increase the willingness to pay (WTP). The cost of growing hydroponic might cause it as higher than traditional (soil agriculture) that drives higher prices. Instead of only focus on WTP, attitude and purchase intention are two constructs that important to estimate actual purchase behavior. However, a study about the antecedents of hydroponic vegetable' purchase intention is still limited. This study aims to identify factors that can enhance purchase intention, group respondents based on those factors, and profile each respondent's group. By online survey, 981 respondents were collected, and multiple regressions and cluster analysis analyzed further data. The result shows eight factors that could drive purchase intention (attitude, subjective norm, perceived behavioral control, perceived quality, price, availability, health consciousness, and knowledge), while environmental concern was not significant. Cluster analysis generates 3 clusters of respondents that have different profiles based on all factors and demographics variables. This study contributes to portraying respondents' responses toward hydroponics that could deliver implications for entrepreneurs or marketers to attract target consumers based on all factors and develop a strategy based on their profiles.
\end{abstract}

\section{Introduction}

In a pandemic situation, people are more concerned about their health and how to increase and maintain their immunity to spared and survive from Covid-19 or other diseases. Even though people have paid more attention to nutrition and food quality, this issue becomes everyone's priority and does a healthy lifestyle. As guidance to drive this healthy lifestyle, someone needs to consume healthy food by eating fruit and vegetables, minimizing sugar, and exercising regularly [1].

To produce such quality food, people more critical against the use of pesticides in agriculture and more concerned about ecological food. Consumers feel they had to protect the environment by choosing products that create less pollution or more environmental concern [2], saving the planet that is green products [3]. When someone considers green

*Corresponding author: tengku.ezni@ui.ac.id 
food, consumers concern about pollution and ecological knowledge, these environmental products were expensive, so customers feel unfair and influence willingness to pay [4]. Considering sustainable food consumption, more consumers change their choice to address environmental issues: organic food [5-7]. Premium price-as economic factor is one of the challenges of organic food because it could lower repeat purchases [8]. From the producer perspectives, as organic food relies on organic farming, it is vulnerable to pests that make crop yield unstable and affect the supply chain and distribution [9]. Furthermore, organic crops grow without chemical pesticides but sometimes use fertilizer from animal manure potentially contaminated with bacteria.

Unlike organic crops or vegetables, another product concerned with environmental sustainability and healthy food is hydroponic. In this condition, the plant can be grown without soil but other nutrient media and water [10]. Agriculture that relies on nutritional water is considered more manageable and can be done at any time regardless of the seasons. This way is very different from agriculture, using the soil as a growing medium, which requires various preparations, such as cultivating the ground and other practices. The hydroponic system also does not use pesticides so that it can produce healthier vegetables and fruits. Besides, farming with this system can be done at any time, regardless of the seasons. The global market of hydroponic is expected to grow in 2025 [11]. In the Asia Pacific, an increasing population will require an agricultural strategy to provide adequate food and population growth.

This case is related to the growing need and as a potential market for hydroponic vegetables. Hence, it is crucial to understand the characteristics of the target market of hydroponic vegetables that can enhance their purchase intention, product attributes, and individual pro-environmental behavior. Previous studies in hydroponic not as many as studies in organic food, and focus on willingness to pay (WTP). Investigation of [12] showed consumers' knowledge and perception towards the health benefits that influence WTP of hydroponic tomatoes in Trinidad. Moreover, an experimental study of [13] revealed if participants $\mathrm{k}$ about some services of hydroponics growing of lettuce, such as environmental, clean, and local benefits, their WTP would increase. The cost of increasing hydroponic may cause these researchers interested in WTP as higher than traditional (soil agriculture) that drive higher price [14], and expect WTP as the antecedent of purchase intention as WTP reflected the price of products. Instead of only focus on WTP, attitude, and purchase intent are constructs that important to estimate actual purchase behavior [15]. However, a study about the antecedents of hydroponic vegetable' purchase intention is still limited.

The study of [16] exhibits the importance of knowledge to develop a positive attitude. When hydroponic is grown by artificial light in Japan, learning about the product will lead to a positive attitude toward hydroponic [16] and an attitude toward hydroponic that uses LED light to enhance purchase intention [17]. Other factors were pricing, sensory evaluation, and perceived benefit as the antecedents of willingness to buy or purchase the meaning of hydroponically grown broccoli microgreens in Alabama [18].

Organic food's popularity drives many researchers to study organic food, particularly identifying the antecedents that influence consumers' responses [3, 4, 6, 19]. However, The study about consumer response to hydroponic vegetables is still limited. This study will build a research framework concerning previous research on organic food due to the little research on hydroponic purchase intention.

In Indonesia, hydroponic has not attracted much attention to entrepreneurs. Unlike organic food's popularity, the household still manages hydroponic plants to fulfill their household's or relatives' needs. Likewise, it is unclear how consumers respond to hydroponic and how to increase their intention to buy hydroponic vegetables. Considering that there is still limited research on consumer behavior related to hydroponics, this study 
aims to identify what factors could influence hydroponic vegetables' purchase intention and develop target consumer clusters. For this reason, this research initially attempts to identify factors (economic and ecological) that could affect the purchase intention of hydroponic vegetables. Further, this research wants to discover the consumer profiles in each cluster. Besides, this research attempt to examine the faces of each segment.

\subsection{Hydroponic}

Hydroponics is a method of growing plants. It uses different materials to support the plant's roots and grow crops directly in nutrient-rich water [10]. Plant attain all their nourishments via nutrient-enriched water [12]. In terms of increasing hydroponic, there are some approaches in the hydroponic system [20], namely fresh water, oxygen, root supports, light, and nutrients. So, hydroponic operations may usually create sustainability advantages relative to soil plants [21]. Hydroponic could produce higher yields than soil-based agriculture, no pesticide use, and food cleaner [22], eco-friendly, and highly productive method [23].

Nowadays, concerning environmental issues, hydroponic systems have been considered to be consumed. However, there is some concern about this system because the different hydroponic characteristics delivered the other responses. Hydroponic has some limitations, such as higher overhead cost, microbiological contamination, need for electricity, and water quality [14]. There was also concern with the willingness to pay [12, 21]. The study of [18] showed respondents perceived differences in appearance between farm-soil vs. farmhydroponic microgreens, even though similar smell and taste.

\subsection{Theory of planned behavior}

Theory of Planned Behavior (TPB) explains the determinant of the formation of behavior intention, namely attitudes, subjective norms, and perceived behavioral control [15]. These antecedents drive individual choice to perform given behavior. Preferences were assumed as motivational factors that indicate an effort to complete the action. In sustainability products or services, some researchers use these factors to affect purchase intention for green products [24-26], green restaurant [27], organic food [28-30], and energy-saving sense [31]. Attitude toward the behavior refers to how the right individual to conduct specific action. Subjective norm refers to the perceived social pressure to perform or not to perform the behavior. Lastly, perceived behavioral control refers to how individuals can control their behavior, including perceived ease or difficulty performing a specific action, reflecting the experience and anticipated impediments and obstacles.

Therefore, in the context of the hydroponic product, this study hypothesis:

$\mathrm{H}_{1}$ : Attitude has a positive effect on the intention to purchase of hydroponic vegetables.

$\mathrm{H}_{2}$ : Subjective Norm has a positive effect on the intention to purchase of hydroponic vegetables.

$\mathrm{H}_{3}$ : Perceived Behavioral Control has a positive effect on the intention to purchase of hydroponic vegetables.

\subsection{Product attributes}

Product quality is related to some attributes and characteristics that could develop positive perception as good quality indicates how well and reliable the product performs its functions [32]. It is not the only perception. Perceived quality will lead to a purchase decision [33]. Some studies demonstrated the positive influence of organic food quality on 
purchase intention $[32,34,35]$. Other factors that could have an impact on consumer decision making are pricing and availability. Price is related to what a customer must give up to get the firm's benefits regarding the amount of money charged for the product/services [36]. In organic food, price is essential because it certifies organic foods are more expensive [26]. Therefore, the price could deter the purchase of organic food [34]. However, if the consumer will show a positive response toward price, they perceive price according to the benefits and quality [26], and fair based on the higher production [4].

The next factor is product availability. Availability means how easy customers buy the products related to where they can buy the product, consider when and how much they need it [36]. Consumers need to spend more time searching and finding the work, making them provide time or money to buy and consume the products. Therefore, consumers prefer to have access quickly to decrease their aid to purchase the products. In this situation, the availability of product increase purchase intention.

In the context of the hydroponic product, this study hypothesizes:

$\mathrm{H}_{4}$ : Product Quality has a positive effect on the intention to purchase of hydroponic vegetables.

$\mathrm{H}_{5}$ : Price has a positive effect on the intention to purchase of hydroponic vegetables.

$\mathrm{H}_{6}$ : Availability has a positive effect on the intention to purchase of hydroponic vegetables.

\subsection{Consumer characteristics}

Hydroponic has some advantages, specifically ecological and economic benefits [14]. Considering ecological service, hydroponic is the product that does not use pesticides or other chemicals to harm the environment and healthy to consume. Hence some consumers who concern about those issues could support the production of hydroponic. Environmental concern is related to how they aware of support issues to protect the environment [37]. There were inconsistent results concerning the effect of the ecological crisis on to purchase intention of organic food. The study of [5] showed environmental concern enhances purchase intention. Otherwise, [37] exhibit an insignificant result.

In terms of packaging aspects, environmental concern positively affects intention to choose ecologically responsible packaging [38]. Hence, there is still needed to study its role as altruistic motives to purchase hydroponic vegetables. It is concerning buying organic food as pro-environmental behavior [37], as well as hydroponic vegetables.

$\mathrm{H}_{7}$ : Environmental Concern has a positive effect on the intention to purchase of hydroponic vegetables

Some studies also revealed how individual health consciousness contribute to purchase intention. Health consciousness is related to how they concern about their health in daily activities. Therefore they had a positive attitude toward organic food [29] and will consume healthier products [39], including organic food [4, 37]. Hydroponic can be categorized as a healthy product because it is not a pesticide crop. Hence, this study hypothesizes:

H8: Health Consciousness has a positive effect on the intention to purchase of hydroponic vegetables.

To reduce uncertainty and risk when consuming a new product, consumers will collect some information to develop their understanding of product value compared to other outcomes [33]. Consumers also need to know what they purchase to satisfy their needs and wants [29].

$\mathrm{H}_{9}$ : Knowledge has a positive effect on the intention to purchase of hydroponic vegetables. 


\section{Method}

A cross-sectional survey in Indonesia collected data. By self-administered online questionnaires, 981 respondents were selected by purposive sampling, with criteria they know hydroponic vegetables and have not purchased it yet. The questionnaire is developed by conducting a literature review and adaptation from previous research.There are 38 items in questionnaires to measure ten constructs that consist of 4 items of attitude $[25,30,39], 3$ items of subjective norm [6, 25, 30,39], 3 items of perceived behavioral control [25, 30, 39], 3 items of price [29], 6 items of perceived quality [32], 5 items of knowledge [6, 29, 39], 4 items of health consciousness [29, 39], 3 items of availability [29], 3 items of environmental concerns $[25,32]$, and 4 items of purchase intentions $[6,30,32]$. Then, we conduct multiple regression to test the hypothesis and K-means cluster analysis to identify respondents' profiles based on ten constructs.

\section{Results and discussion}

\subsection{Profile and descriptive statistics}

More than half of the respondents are female. In terms of marital status, the majority are married or widow/widower. However, the proportion of age is almost similar between younger and above 30 years old. Interestingly, more than $90 \%$ live with three and more family members. Even though only 65 have a child or more. The respondent profile is shown in Table 1.

Table 1. Profile Respondents.

\begin{tabular}{lll}
\hline Gender & $\mathbf{n}$ & $\mathbf{\%}$ \\
\hline Male & 359 & 36.6 \\
Female & 622 & 63.4 \\
\hline Marital Status & $\mathbf{n}$ & $\mathbf{\%}$ \\
\hline Single & 327 & 33.3 \\
Married & 630 & 64.2 \\
Widow or Widower & 24 & 2.5 \\
\hline Age & $\mathbf{n}$ & $\mathbf{\%}$ \\
\hline 30 years old and less & 492 & 50.2 \\
Above 30 years old & 489 & 49.8 \\
\hline Family Member & $\mathbf{n}$ & $\mathbf{\%}$ \\
\hline 1-2 persons & 77 & 7.8 \\
3-4 persons & 549 & 55.9 \\
above four persons & 355 & 37.2 \\
\hline Number of Children & $\mathbf{n}$ & $\mathbf{\%}$ \\
\hline No child & 345 & 35.2 \\
1 Child & 223 & 22.7 \\
2 Children & 278 & 28.3 \\
3 Children & 103 & 10.5 \\
Above three children & 32 & 3.3 \\
\hline
\end{tabular}

All constructs and item are valid (factor loading $>0.5$ ) and reliable (cronbach alpha> 0.6 ), except PP1 (item 1 of pricing) because the factor loading $=0.47$. This item was deleted for further analysis (Table 2). 
Table 2. Descriptive statistics.

\begin{tabular}{|l|c|c|c|c|c|c|c|}
\hline Construct & $\begin{array}{c}\text { Number } \\
\text { of items }\end{array}$ & $\begin{array}{c}\text { Loading } \\
\text { Factor }\end{array}$ & $\begin{array}{c}\text { Cronbach } \\
\text { alpha }\end{array}$ & $\begin{array}{c}\text { Mini- } \\
\text { mum }\end{array}$ & $\begin{array}{c}\text { Maxi- } \\
\text { mum }\end{array}$ & Mean & $\begin{array}{c}\text { Std. } \\
\text { Deviation }\end{array}$ \\
\hline Attitude & 4 & $0.70-0.91$ & 0.89 & 1.00 & 5.00 & 4.43 & 0.68 \\
\hline Subject Norm & 3 & $0.88-0.91$ & 0.92 & 1.00 & 5.00 & 3.60 & 1.03 \\
\hline $\begin{array}{l}\text { Preceived } \\
\text { Beavioral } \\
\text { Control }\end{array}$ & 3 & $0.58-0.87$ & 0.75 & 1.00 & 5.00 & 4.06 & 0.83 \\
\hline Price & 2 & 0.94 & 0.86 & 1.00 & 5.00 & 4.33 & 0.76 \\
\hline Knowledge & 5 & $0.59-0.68$ & 0.75 & 1.00 & 5.00 & 4.15 & 0.70 \\
\hline $\begin{array}{l}\text { Preceived } \\
\text { Quality }\end{array}$ & 6 & $0.73-0.79$ & 0.89 & 1.00 & 5.00 & 3.96 & 0.84 \\
\hline Availability & 3 & $0.67-0.93$ & 0.81 & 1.00 & 5.00 & 3.57 & 0.97 \\
\hline $\begin{array}{l}\text { Environmental } \\
\text { Concern }\end{array}$ & 3 & $0.65-0.89$ & 0.68 & 1.00 & 5.00 & 4.69 & 0.51 \\
\hline $\begin{array}{l}\text { Health } \\
\text { Consciousness }\end{array}$ & 4 & $0.79-0.87$ & 0.89 & 1.00 & 5.00 & 4.53 & 0.61 \\
\hline $\begin{array}{l}\text { Purchase } \\
\text { Intention }\end{array}$ & 3 & $0.83-0.92$ & 0.93 & 1.00 & 5.00 & 4.02 & 0.91 \\
\hline
\end{tabular}

\subsection{Hypothesis testing}

Multiple regression was used to test 9 hypotheses (Table 3). This research uses factor score as a composite score in regression analysis, and the result demonstrated $\mathrm{H}_{7}$ is not significant $(\alpha=5 \%)$.

Table 3. Multiple regression analysis.

\begin{tabular}{lcccc}
\hline & $\boldsymbol{\beta}$ & t-value & Sig. & Conclusion \\
\hline $\begin{array}{l}\text { Dependent Variable } \\
\text { Purchase Intention } \\
\text { Independent Variables }\end{array}$ & & & & \\
\hline $\mathrm{H}_{1}$ : Attitude & 0.118 & 4.267 & 0.000 & $\mathrm{H}_{1}$ supported \\
$\mathrm{H}_{2}$ : Subject Norm & 0.171 & 6.325 & 0.000 & $\mathrm{H}_{2}$ supported \\
$\mathrm{H}_{3}$ : Preceived Beavioral & 0.069 & 2.434 & 0.015 & $\mathrm{H}_{3}$ supported \\
Control & 0.230 & 8.108 & 0.000 & $\mathrm{H}_{4}$ supported \\
$\mathrm{H}_{4}$ : Product Quality & 0.182 & 66.80 & 0.000 & $\mathrm{H}_{5}$ supported \\
$\mathrm{H}_{5}:$ Price & 0.071 & 3074 & 0.002 & $\mathrm{H}_{6}$ supported \\
$\mathrm{H}_{6}:$ Availability & 0.039 & 1.825 & 0.068 & $\mathrm{H}_{7}$ not supported \\
$\mathrm{H}_{7}$ : Environmental Concern & 0.100 & 4.022 & 0.000 & $\mathrm{H}_{8}$ supported \\
$\mathrm{H}_{8}:$ Health Conciouness & 0.116 & 3.595 & 0.000 & $\mathrm{H}_{0}$ supported \\
H0: Knowledge & & & &
\end{tabular}

\subsection{Cluster analysis}

This section aims to develop a cluster of respondents based on their similarities in terms of factors that influence purchase intention. In defining the number of groups, first, we run hierarchical cluster analysis. Using the dendrogram and agglomeration matrix, we identify the number of clusters in range 3-5. Refer to [40]. In this research, three clusters are meaningful, so we conduct K-Means 3 clusters (Table 4). The cluster analysis result showed that respondents were grouped into three distinct clusters based on their response to all factors that could influence purchase intention and purchase intention. A respondent 
with "High Supported-High Interested," "Quite Supported-Quite Interested," and "Not Supported-Not Interested." All groups have an almost similar high mean score of health consciousness and environmental concern representing all groups that balance altruistic motives and health' motives. The difference is seen in the subjective norm, perceived quality, and availability. Cluster 1 illustrates a group of respondents highly supported by their family (mean score of the personal standard is 4.35). Otherwise, this score is lowest in cluster 3. So is the mean score of purchase intention representing how interested in purchasing hydroponic vegetables. Cluster 1 has the highest mean score. Conversely, cluster 3 has the lowest mean score of purchase intention.

In an attempt to clarify more enriching each cluster's profile, Table 5 shows that respondents with High Supported-High Interested (cluster 1) are mostly females (66.7 percent). Married (67\%), almost the same age proportion between less than 30 years old and above (around 50\%), mostly live with 3-4 family member (57.6\%), and no children $(33 \%)$. Interestingly, in terms of education, cluster 1 has the lowest proportion of respondents with undergraduate and above (38.8\%) compare to cluster $2(51.5 \%)$ and cluster $3(58.9 \%)$, likewise the gender proportion. Cluster 1 has the lowest proportion of male respondents (33\%) compare to cluster $2(38.7 \%)$ and cluster $3(41.1 \%)$.

Table 4. The cluster of respondents.

\begin{tabular}{|l|c|c|c|c|c|}
\hline \multicolumn{1}{|c|}{ Construct } & Cluster 1 & Cluster 2 & Cluster 3 & F-value & Sig. \\
\hline Attitude & 4.84 & 4.35 & 3.50 & 458.366 & 0.000 \\
\hline Subject Norm & 4.35 & 3.27 & 2.26 & 635.088 & 0.000 \\
\hline $\begin{array}{l}\text { Preceived Beavioral } \\
\text { Control }\end{array}$ & 4.66 & 3.80 & 3.00 & 601.961 & 0.000 \\
\hline Preceived Price & 4.81 & 4.22 & 3.27 & 530.562 & 0.000 \\
\hline Knowledge & 4.69 & 3.87 & 3.27 & 705.062 & 0.000 \\
\hline Preceived Quality & 4.51 & 3.79 & 2.82 & 523.674 & 0.000 \\
\hline Availability & 4.25 & 3.14 & 2.65 & 389.529 & 0.000 \\
\hline Environmental Concern & 4.86 & 4.59 & 4.43 & 61.794 & 0.000 \\
\hline Health Consciousness & 4.83 & 4.39 & 4.02 & 161.341 & 0.000 \\
\hline Purchase Intention & 4.70 & 3.79 & 2.66 & 900.949 & 0.000 \\
\hline Number of Respondents & 451 & 367 & 163 & & \\
\hline
\end{tabular}

Table 5. Demographic profile in each cluster.

\begin{tabular}{|c|c|c|c|c|c|c|}
\hline \multirow{3}{*}{ Demographics } & \multicolumn{2}{|c|}{$\begin{array}{c}\text { Cluster 1: } \\
\text { High Supported- } \\
\text { High Interested }\end{array}$} & \multicolumn{2}{|c|}{$\begin{array}{c}\text { Cluster 2: } \\
\text { Quite Supported- } \\
\text { Quite Interested }\end{array}$} & \multicolumn{2}{|c|}{$\begin{array}{c}\text { Cluster 3: } \\
\text { Not Supported- } \\
\text { Not Interested }\end{array}$} \\
\hline & \multicolumn{2}{|c|}{$N=451$} & \multicolumn{2}{|c|}{$\mathrm{N}=367$} & \multicolumn{2}{|c|}{$N=163$} \\
\hline & \multicolumn{2}{|c|}{$(45.9 \%)$} & \multicolumn{2}{|c|}{ (37.5\%) } & \multicolumn{2}{|c|}{$\mathrm{N}=163(16.6 \%)$} \\
\hline \multicolumn{7}{|l|}{ Gender } \\
\hline Male & 150 & $33.3 \%$ & 142 & $38.7 \%$ & 67 & $41.1 \%$ \\
\hline Female & 301 & $66.7 \%$ & 225 & $61.3 \%$ & 96 & $58.9 \%$ \\
\hline Marital status & & & & & & \\
\hline
\end{tabular}




\begin{tabular}{|l|c|c|c|c|c|c|}
\hline Single & 138 & $30.6 \%$ & 126 & $34.3 \%$ & 63 & $38.7 \%$ \\
\hline Married & 302 & $67.0 \%$ & 231 & $62.9 \%$ & 97 & $59.5 \%$ \\
\hline Widow or Widower & 11 & $2.4 \%$ & 10 & $2.7 \%$ & 3 & $1.8 \%$ \\
\hline Age & & & & & & \\
\hline Less than 30 years old & 238 & $52.8 \%$ & 175 & $47.7 \%$ & 79 & $48.5 \%$ \\
\hline Above 30 years old & 213 & $47.2 \%$ & 192 & $52.30 \%$ & 84 & $51.5 \%$ \\
\hline Family member & & & & & & \\
\hline $1-2$ persons & 28 & $6.2 \%$ & 27 & $7.4 \%$ & 22 & $13.5 \%$ \\
\hline $3-4$ persons & 260 & $57.6 \%$ & 203 & $55.3 \%$ & 86 & $52.8 \%$ \\
\hline above 4 persons & 163 & $36.2 \%$ & 137 & 37.3 & 55 & $33.8 \%$ \\
\hline Number of Children & & & & & & \\
\hline No children & 150 & $33.3 \%$ & 126 & $34.3 \%$ & 69 & $42.3 \%$ \\
\hline 1 child & 106 & $23.5 \%$ & 84 & $22.9 \%$ & 33 & $20.2 \%$ \\
\hline 2 children & 144 & $31.9 \%$ & 93 & $25.3 \%$ & 41 & $25.2 \%$ \\
\hline 3 children & 34 & $7.5 \%$ & 53 & $14.4 \%$ & 16 & $9.8 \%$ \\
\hline above 3 children & 17 & $3.8 \%$ & 11 & $3.0 \%$ & 4 & $2.5 \%$ \\
\hline Education & 207 & $45.9 \%$ & 134 & $36.5 \%$ & 60 & $36.8 \%$ \\
\hline Junior School & 150 & $33.3 \%$ & 152 & $41.4 \%$ & 74 & $45.4 \%$ \\
\hline High School & 25 & $5.5 \%$ & 37 & $10.1 \%$ & 22 & $13.5 \%$ \\
\hline Diploma & & & & & & \\
\hline Bachelor & & & & & & \\
\hline Master and Doctoral & & & & & & \\
\hline & & & & & & \\
\hline
\end{tabular}

\subsection{Discussion}

Our findings indicate all antecedents in the Theory of Planned Behavior are significant. The more positive attitude toward purchasing hydroponic, the higher supporting by relatives, and the higher control of purchasing hydroponic, the higher intention to purchase it. When respondents perceived they have control over purchasing hydroponic, it leads to buy the products [41]. In the organic food context, attitude, subjective norm, and perceived behavioral control positively influence purchase intention directly [4, 39]. As hydroponic is no pesticide plant, these products are healthy products, like organic food. These characteristics of hydroponic will provide benefits for people who care about their health as the respondent's belief that his work safe to consume [13], reliable [16], enhance positive attitude [29]. It is supported by the significant influence of health consciousness toward purchase intention as well. This result in line with the study of $[4,29,39]$ in terms of 
organic food. Higher health consciousness of respondents will lead to higher intention to purchase hydroponic.

Other useful drivers of purchase intention hydroponic are perceived quality, price, availability, and knowledge. When respondents believe that hydroponic deliver higher quality than organics and conventional, it intends to purchase it. From now on, if the price of hydroponic consistent with quality and benefit, easy to find and available in many places, and respondents have higher knowledge about hydroponic in terms of process and the characteristic (attributes), this situation will encourage purchase intention. This study showed similar results on how perceived quality increased purchase intention [32], price and knowledge indirectly influence purchase intention [29].

Interestingly, this study exhibits environmental concern is not significant to enhance purchase intention. Even though respondents have a high mean score of the ecological crisis that reflects their relationship with humans' importance to protect the environment, these altruistic motives could not lead them to purchase hydroponic vegetables. A study of [4] in three countries showed a mixed result. There was a positive relationship between environmental concern and purchase intention in Pakistan, but Turkey and Iran did not prove it. The research revealed that instead of altruistic motive (environmental concern), economic or egoistic reason (quality, price, availability, knowledge) has a higher impact on hydroponic purchase intention.

\section{Conclusion}

This study has two main objectives: 1) to identify what factors could influence the purchase intention of hydroponic vegetables, and 2) develop target consumer clusters based on those factors. The result demonstrated attitude, subjective norm, perceived behavioral control, product quality, price, availability, health consciousness, and knowledge could enhance the intention to purchase hydroponic vegetables. Product quality and price are two factors that have a higher impact on purchase intention. Meanwhile, environmental concern as an altruistic motive does not impact on purchase intention.

There are three clusters when we consider respondents profile: highly supported-highly interested, quite supported-quite interested, and not supported-not interested. These clusters differ mostly in terms of the level of support by relatives and intention.

Our study contributes theoretically by identifying and using the logic of model development by previous researchers on organic food. These eight factors can enhance the purchase intention of hydroponic as a pro-environmental or ecological product. These research findings suggest that product quality and pricing are two factors that contribute to strengthening purchase intention. Different purchase intention levels and the other three clusters' profiles will guide entrepreneurs to target their hydroponic vegetables optimally. If they focus on single, male, and older target consumers, entrepreneurs have to design more initiatives to increase purchase intention by focusing on quality and price. This cluster 3 is less support by their relatives. Therefore entrepreneurs must consider influencing and develop their belief about the value of hydroponic vegetables directly, not mediated by their relatives.

This study only concerns the direct effect of these antecedents to purchase intention, and there is no significant effect of environmental concern as hydroponics is a proenvironmental product. This result less congruent with the importance of altruistic motives in explaining consumer responses. Further study should consider these factors' potential indirectly affecting purchase intention, as an antecedent of attitude or as moderator of all aspects. 


\section{References}

1. WHO, A healthy lifestyle (2020) https://www.euro.who.int/en/health-topics/diseaseprevention/nutrition/a-healthy-lifestyle

2. J.A Roberts, D.R. Bacon, Exploring the subtle relationships between environmental concern and ecologically conscious consumer behavior, Journal of Business Research 40, 79 (1997) https://doi.org/10.1016/S0148-2963(96)00280-9

3. B. Shen, S. Liu, T. Zhang, T.M. Choi, Optimal advertising and pricing for new green products in the circular economy, Journal of Cleaner Production 233, 314 (2019) https://doi.org/10.1016/j.jclepro.2019.06.022

4. S. Dekhili S, M. Achabou, Price fairness in the case of green products: enterprises' policies and consumers' perceptions: price fairness, Bus. Strat. Env. 22, 547 (2013) https://doi.org/10.1002/bse.1763

5. M. Asif, W. Xuhui, A. Nasiri, S. Ayyub, Determinant factors influencing organic food purchase intention and the moderating role of awareness: a comparative analysis, Food Quality and Preference, 63144 (2018) https://doi.org/10.1016/j.foodqual.2017.08.006

6. N Dangi, S.A. Narula, S.K. Gupta, Influences on purchase intentions of organic food consumers in an emerging economy, Journal of Asia Business Studies (2020) https://doi.org/10.1108/JABS-12-2019-0364

7. G. Rizzo, M. Borrello, G.D. Guccione, G. Schifani, L. Cembalo, Organic food consumption: the relevance of the health attribute, Sustainability 12, 12 (2020) https://doi.org/10.3390/su12020595

8. L. Marian, P. Chrysochou, A. Krystallis, J. Thøgersen, The role of price as a product attribute in the organic food context: An exploration based on actual purchase data, Food Quality and Preference, 3752 (2019) https://doi.org/10.1016/j.foodqual.2014.05.001

9. Global Crop Production, Market Report 2020-30: COVID-19 Impact and Recovery (2020) https://www.researchandmarkets.com

10. H.M. Resh, Hydroponic Food Production: A Definitive Guidebook for the Advanced Home Gardener and the Commercial Hydroponic Grower 7 ed, CRC Press, (2016)

11. Hydroponics Market, Growth Trends and Forecast (2020 - 2025) (2020) https://www.researchandmarkets.com/reports/4703410/hydroponics-market-growthtrends-and-forecast

12. L.K. Narine, W. Ganpat, A. Ali, Consumers willingness to pay for greenhousehydroponic tomatoes in Trinidad,WI Tropical Agriculture 91, 266 (2014)

13. D. Gilmour, Consumers' willingness to pay for hydroponic lettuce, Theses. University of Arkansas, 2722, (2018) https://scholarworks.uark.edu/etd/2722/

14. C. Treftz, S.T. Omaye, Hydroponics: potential for augmenting sustainable food production in non-arable region, Nutrition \& Food Science 46, 672 (2016) https://doi.org/10.1108/NFS-10-2015-0118

15. I. Ajzen, The theory of planned behavior: organizational behavior and human decision processes, theories of cognitive self-regulation, Organizational Behavior and Human Decision Processes 50, 179 (1991) https://doi.org/10.1016/0749-5978(91)90020-T

16. Y. Yano, T. Nakamura, A. Maruyama, Consumer perceptions toward vegetables grown in plant factories using artificial light- an application of the free word association method, Focusing on Modern Food Industry 4, 11 (2015) https://www.doi.org/10.14355/fmfi.2015.04.002

17. Y.H. Wu, Y.H. Kuo, Using TAM to investigate consumer acceptance of Hydroponic Vegetables grown using LED light, The International Journal of Organizational Innovation 8, 260 (2016) 
18. H. Chen, X Tong, L Tan, L. Kong, Consumers' acceptability and perceptions toward the consumption of hydroponically and soil grown broccoli microgreens, Journal of Agriculture and Food Research 2, 6 (2020) https://doi.org/10.1016/j.jafr.2020.100051

19. Q. Tong, S. Anders, J. Zhang, L. Zhang, The roles of pollution concerns and environmental knowledge in making green food choices: Evidence from Chinese consumers, Food Research International 130, 10 (2020) https://doi.org/10.1016/j.foodres.2019.108881

20. Verticalroots, What is hydroponic farming? Why use hydroponics? (2020) https://www.verticalroots.com/the-what-and-why-of-hydroponic-farming/

21. D.N. Gilmour, R.M. Nayga, C. Bazzani, H. Price, Consumers' willingness to pay for hydroponic lettuce: a non-hypothetical choice experiment, Southern Agricultural Economics Association Annual Meeting, 2-6 February 2018, Jacksnville, Florida (2018) https://doi.org/10.22004/ag.econ.26668

22. What is Hydroponics? : What is the heck of hydroponics? https://generalhydroponics.com/about-us

23. N. Sharma, S. Acharya, K. Kumar, N. Singh, O.P. Chaurasia, Hydroponics as an advanced technique for vegetable production: An overview, Jour. of Soi. and Wat. Conser. 17, 364 (2018) https://10.5958/2455-7145.2018.00056.5

24. S. Emekci, Green consumption behaviors of consumers within the scope of TPB, Journal of Consumer Marketing 36, 410 (2019) https://doi.org/10.1108/JCM-05-2018$\underline{2694}$

25. J. Paul, A. Modi, J. Pate, Predicting green product consumption using theory of planned behavior and reasoned action, Journal of Retailing and Consumer Services 29, 123 (2016) https://doi.org/10.1016/j.jretconser.2015.11.006

26. N. Sreen, S. Purbey, P. Sadarangani, Impact of culture, behavior and gender on green purchase intention, Journal of Retailing and Consumer Services 41, 189 (2018) https://doi.org/10.1016/j.jretconser.2017.12.002

27. A. Tommasetti, P. Singer, O. Troisi, G. Maione, Extended theory of planned behavior (ETPB): investigating customers' perception of restaurants' sustainability by testing a structural equation model, Sustainability 10, 21 (2018) https://www.doi.org/10.3390/su10072580

28. D. Pandey, A. Kakkar, M. Farhan, T.A. Khan, Factors influencing organic foods purchase intention of Indian customers, Org. Agr. 9, 357 (2019) https://doi.org/10.1007/s13165-018-0240-z

29. A. Singh, P. Verma P, Factors influencing Indian consumers' actual buying behaviour towards organic food products, Journal of Cleaner Production 167, 473 (2017) https://doi.org/10.1016/j.jclepro.2017.08.106

30. M. Yazdanpanah, M. Forouzani, Application of the Theory of Planned Behaviour to predict Iranian students' intention to purchase organic food, Journal of Cleaner Production 107342 (2015) https://doi.org/10.1016/j.jclepro.2015.02.071

31. X. Liu, Q. Wang, H.H. Wei, H.L. Chi, Y. Ma, I.Y. Jian, Psychological and demographic factors affecting household energy-saving intentions: a TPB-based study in Northwest China, Sustainability 12, 20 (2020) https://doi.org/10.3390/su12030836

32. J. Wang, T.L. Pham, V.T. Dangm, Environmental consciousness and organic food purchase intention: a moderated mediation model of perceived food quality and price sensitivity, Int. J. Environ. Res. Public Health 17, 18 (2020) https://doi.org/10.3390/ijerph17030850

33. G.W. Marshall, M.W. Johnston, Marketing Management 3rd Ed. (McGraw-Hill Education, New York, 2018)

34. N.C. Lago, A. Marcon, J.L.D. Ribeiro, J.F. de Medeiros, V.B. Brião, V.L. Antoni, Determinant attributes and the compensatory judgement rules applied by young 
consumers to purchase environmentally sustainable food products, Sustainable

Production and Consumption 23, 1 (2020) https://doi.org/10.1016/j.spc.2020.06.003

35. M. Massey, A. O'Cass, P. Otahal, A meta-analytic study of the factors driving the purchase of organic food, Appetite 125418 (2018) https://www.doi.org/10.3390/foods9010079

36. W.D. Perreault, J.P. Cannon, E.J. McCarthy, Essentials of Marketing: A Marketing Strategy Planning Approach 15th Ed (McGraw-Hill Education, New York, 2017)

37. R. Yadav, G.S. Pathak, Intention to purchase organic food among young consumers: Evidences from a developing nation, Appetite 96, 122 (2015) https://doi.org/10.1186/s12889-019-7118-1

38. L.N. Koenig, A. Palmer, J. Dermody, A. Urbye, Consumers' evaluations of ecological packaging - Rational and emotional approaches, Journal of Environmental Psychology 37, 22 (2014) https://doi.org/10.1016/j.jenvp.2013.11.009

39. X. Wang, F. Pacho, J. Liu, R. Kajungiro, Factors influencing organic food purchase intention in developing countries and the moderating role of knowledge, Sustainability 11, 209 (2019) https://doi.org/10.3390/su11010209

40. N.K. Malhotra, Marketing Research: An Applied Orientation (Pearson Education, New York, 2010)

41. K. Jürkenbeck, A. Heumann, A. Spiller, Sustainability matters: consumer acceptance of different vertical farming systems, Sustainability 11, 21 (2019)

https://doi.org/10.3390/su11154052 